\title{
THE BACTERIOPHAGES IN THE TREATMENT OF PERITONITIS OF APPENDICULAR ORIGIN
}

\section{Olga Peltikhina ${ }^{1} \mathbb{C}_{\text {, Artem Morozov }}{ }^{(D)}$, Vladimir Murga ${ }^{1 \bowtie}$ (iD, Oleg Konovalov ${ }^{2}$ (D), Sergey Zhukov'}

\author{
${ }^{1}$ Tver State Medical University, Tver, Russia \\ ${ }^{2}$ People's Friendship University of Russia, (RUDN), Moscow, Russia
}

childtv@mail.ru
A B S TRACT — Due to development of laparoscopic techniques for the surgical treatment of acute appendicitis, the problem of the occurrence of early postoperative complications has not changed at present, which makes it necessary to carry out preventive measures. In the present study, one of the most frequent complications of acute appendicitis, peritonitis, has been modeled on the example of a biological model, with the aim of developing a method of preventive measures. The group of authors considered antibiotic prophylaxis, as well as an alternative method of preventive perioperative bacteriophage therapy. The evaluations method was based on the study of the clinical picture of the course of peritonitis in experimental animals, the pathomorphological and histological examination of the sectional peritoneum. As the result of the study, the authors did not reveal a significant difference in the methods of perioperative prophylaxis of complications of acute appendicitis, which makes possible to conduct monotherapy with bacteriophages, which is a promising direction in the face of ever increasing antibiotic resistance to antibacterial chemotherapy drugs.

KEYW ORDS - acute appendicitis, peritonitis, bacteriophages, perioperative bacteriophage therapy.

Among acute surgical diseases of the abdominal organs, acute appendicitis is one of the most common. The incidence of acute appendicitis is approximately equal in all countries of the world and rates between 4 and 5 cases per 1000 people per year. The patients mortality with acute appendicitis according to different authors, varies from $0.14 \%$ to $0.5 \%$, while for older people it reaches $4.6 \%$, exceeding the average statistics in 10 times [1]. The number of early infectious complications after appendectomy, according to various sources, rates from 4 to $20 \%$ and practically did not decrease due to the use of laparoscopic surgical equipment. The problem of postoperative appendectomy complications remains relevant and require the search for ways to prevent these complications $[2,3,4]$. One of preventions type is bacteriophage therapy. According to some authors, bacteriophages have great potential in the fight against pathogenic microorganisms $[5,6,7]$.
The purpose of the study

was to study the possibility of improving the surgical treatment results of peritonitis, the most common complication of acute appendicitis, by reducing the number of postoperative complications of infectious genesis.

The problem was solved in the experiment by comparative assessment of the conservative fragment results of simulated peritonitis treatment using antibiotic therapy and combination therapy with bacteriophages.

\section{MATERIALS AND METHODS}

Studies were performed on 47 non-linear white rats weighing 200-250 g.

To simulate peritonitis was used infection of the abdominal cavity the museum strain of E. Coli 25922.

The immunodeficiency state of experimental animals was caused by limiting calorie intake for 5 days. The rats abdominal hair was shaved and the surface of the stomach was extracted with a $70 \%$ alcohol solution. Then the abdominal wall was pierced perpendicularly at the base of the skin fold, then the needle was passed along the fold and the suspension of the E. coli museum strain was injected with 10 billion microns. bodies per $100 \mathrm{~g}$ of rat mass in two ml of physiological saline.

The studied laboratory animals were divided into three groups. The first group (control) contains 3 animals. Rats received no treatment.

The second group contains 20 animals. Rats received treatment in the form of a single intraperitoneal administration of Cefipim at the rate of 100 milligrams per $\mathrm{kg}$ body mass in two $\mathrm{ml}$ of physiological saline.

The third group contains 20 animals. Rats received treatment in the form of a single intraperitoneal injection of $2.5 \mathrm{ml}$ of Sextophagus.

The animals were removed from the experiment on days 3, 7 and 14 by overdosing an anesthetic drug (in accordance with the principles of humane treatment of laboratory animals).

Evaluation of the results was carried out according to the clinical picture, the state of the abdominal cavity and the macroscopic and histological (with hematoxylin and eosin staining) examination of the preparations of the intestine and parietal peritoneum.

\section{RESULTS}

On the first day of the experiment, there was no significant change in the clinical picture in animals. 
There was observed lethargy, appetite was not modified.

On the second day of the experiment, 38 animals began to manifest a general clinical picture of peritonitis: hypodynamism, lethargy, animals tried not to leave the corners of the cell, ruffled hair, rapid breathing, and loose stools were noted. There was a sharp decrease in appetite.

By the third day, a similar clinical picture developed in 45 animals. Two animals showed no signs of an inflammatory reaction of the body. On the third day, two animals were withdrawn from experiments with sampling material. At autopsy, one to three $\mathrm{ml}$ of fibrinous-purulent peritoneal exudate was found in the abdominal cavity of rats. The inside of the abdominal wall was reddened, dull with fibrin overlay. Separate small focal hemorrhages were noted on the intestinal mesentery. The loops of the intestines were swollen, in some places, the intestine looked edematous, and the vascular pattern of the intestinal wall seemed strengthened. Histological examination of the sectional material revealed focal and diffuse accumulations of neutrophilic leukocytes between the muscle fibers of the intestinal wall with signs of necrosis, pronounced venous congestion, stromal edema, and perivascular leukocyte infiltration. On the fifth day, three rats from the control group died; in the section, they showed signs of diffuse purulent peritonitis with single perforations of the intestinal loops. On the seventh day, half (10) rats from the second and third groups were removed from the experiment.

In rats of the second group, there was a slight swelling of the intestinal walls, injection of the mesenteric vessels. Histologically, a pronounced neutrophilic infiltration and a moderate macrophage reaction were detected in the walls. The edema of the stroma of the walls and their venous plethora remained.

The third group rats, a similar picture was observed. Histologically determined diffuse leukocyte infiltration of the intestinal walls with a large number of macrophages.

During comparing the results of treatment of experimental peritonitis in rats of the second group (sanitation with an antibiotic solution) and the third group (sanitation with a bacteriophage) on the seventh day, no significant morphological changes in the intestinal walls were detected. At the same time, the impression was made that in the last group the recovery processes in the gut were more actively.

On the fourteenth day, the remaining animals were withdrawn from the experiment.

In rats of the second group, the state of the abdominal cavity for this observation period was close to nor$\mathrm{mal}$; in half of the cases, a moderate adhesion process was noted. Histological examination showed signs of residual inflammation, noticeable venous congestion, moder- ate infiltration of the intestinal walls with neutrophilic leukocytes, and a large number of macrophages.

The third group rats, macroscopic signs of peritonitis were also stopped, small adhesions of the peritoneum were noted. Histologically, an insignificant neutrophilic reaction with a small number of macrophages remained in the intestinal wall. The structure of the peritoneal cover was close to normal.

Finaly treated rats with the antibiotic, by the end of the observation period, residual signs of inflammation of the intestinal wall remained, and in rats treated with the bacteriophage had of the peritoneum structure of the intestine was closer to normal.

\section{CONCLUSIONS}

Thus, our experimental studies have revealed quite satisfactory results of monotherapy by bacteriophage for experimental peritonitis. Phages in comparison with antibiotics have no less therapeutic efficacy. According to morphological data, the inflammatory process in the abdominal cavity stopped through phages rather quickly and at the same time there is a tendency to scale back the inflammation more quickly than with antibiotic treatment.

\section{REFERENCES}

1. Styazhkina S.N., Salavatullin A.V., KuZnecov S.F., Aleksandrov A.YU. Problemnye voprosy hirurgicheskogo lecheniya ostrogo appendicita i ego oslozhnenij// Sovremennye tendencii razvitiya nauki i tekhnologij. 2016. № 3-2. P.55-57

2. MoKhov E.M., KadyKov V.A., Morozov A.M. Prospects for the use of bacteriophages in surgery of acute appendititis // Modern problems of science and education. 2017. №2. P. 129.

3. MoKhov E.M., Morozov A.M., EvstifEeva E.A., FilipPChENKova S.I., Murashova L.A., Kadykov V.A., Peltikhina O.V. The life quality of the patients after laparoscopic prevention with use of bacteriophages in the post-operating period appendititis / Modern problems of science and education. 2018. № 3. P. 76.

4. Aslanov B.I., Zueva L.P., Kaftyreva L.A. Racional'noe primenenie bakteriofagov v lechebnoj $\mathrm{i}$ protivoehpidemicheskoj praktike // Federal'nye klinicheskie rekomendacii - Moskva, 2014 g. 39 p.

5. Briusov P.G., ZubritsKiI V.F., ISLAMOV R.N., Nizovoř A.V., FOMINYKH E.M. Phagoprophylaxis and bacteriophage treatment of surgical infections // Voen Med Zh. - 2011 - 332(4): 34-9.

6. Kutateladze M., Adamia R. Bacteriophages as potential new therapeutics to replace or supplement antibiotics // Trends Biotechnol - 2010 - 28(12): 591-5.

7. Rios AC., Moutinho CG., Pinto FC., Del Fiol FS., Jozala A., Chaud MV., Vila MM., Teixeira JA., BALCÃo VM. Alternatives to overcoming bacterial resistances: State-of-the-art // Microbiol Res - 2016 - 191:51-80. 